\title{
Synchronous reproduction in mussel (Mytilus galloprovincialis) population from atlantic ocean of morocco
}

\begin{abstract}
We investigated the gametogenesis of a natural population of Mytilusgalloprovincialis in the Atlantic central zone (Cape Beddouza). We found that the cycle of reproduction was characterized by a synchronous gametogenesis. From March 2009 to March 2011, we histologically analyzed the status of gonad development and the reserves cells at the peak of spawning. To determine the status of gonad development, we used three biological indecies parameters: the gonadic index, the condition index and the ADG index. The gonadic index was the highest in winter. The condition index was the lowest in spring. The ADG index was the highest in autumn. We found synchrony of these indices in majority of sampled $M$. galloprovincialis. The found synchrony was unique in the populations other waters in Moroccan coast, where gonad development cycle was individually different. The synchrony of reproductive cycle in the population maybe a result of the consistent seasonal pattern of environmental variable along the cape.
\end{abstract}

Keywords: Mytilusgalloprovincialis, Reproduction, Condition index, Gonadic index, ADG cells, Histology Atlantic Ocean
Volume 2 Issue 4 - 2015

\author{
Sanaa Bhaby \\ Department of Aquaticecology and Environnent, University \\ Hassan II, Morocco
}

\begin{abstract}
Correspondence: Sanaa Bhaby, Department of Aquaticecology and Environnent, University Hassan II, Casablanca, Morocco,
\end{abstract} Email sanaa bhaby@gmail.com

Received: June 18,2015 | Published: August 06, 2015

\section{Introduction}

In Moroccan water, M. galloprovincialis distributed from the Mediterranean Sea to the Atlantic Coast. ${ }^{1}$ There are both natural population and aquacultural stocks of $M$. galloprovincialis in this region. In 2005, the gradually increased production of $M$. galloprovincialis reached 34 tons in Moroccan water, but it was at stand still until $2009 .^{2}$ In 2010, the production decreased to less than half of the maximum in recent years. ${ }^{2}$ To maintain a fragile balance between captures and natural renewal of stocks, available information in the M. galloprovincialis in Moroccan water is not sufficient yet.

The natural population of $M$. galloprovincialis has been under potential pressure of local consumption, commercial fisheries and coastal development. However, it has not been well studied in this area. Until 2000, there was only one scientific publication about the general reproductive biology of the $M$. galloprovincialis, discussing the multiple peaks of gonad maturation. ${ }^{3}$ After 2000's, there were two papers of reproductive biology of $M$. galloprovincialis in coastal water of Mediterranean Sea and the Atlantic coast of southern Morocco with detail investigation with histological analyses. ${ }^{4,5}$ There are still many observed habitats and aggregations of $M$. galloprovincialis along Moroccan coast, and those few investigations are not sufficient to understand the natural populations and to monitor their status.

The reproduction of fishery targeted mussels, including $M$. galloprovincialis has been studied in European Atlantic waters . ${ }^{6}$ On the other hand, not many scientific investigations were conducted on the reproductive cycle of mussels in African Atlantic waters. About Mytilus spp. the seasonality and duration of the reproduction were explained by effect of the spatiotemporal variation of the ambient environmental conditions in their habitats. The temperature and the food were suggested as the major exogenous factors which control and regulate the duration and the synchronization of reproductive cycle of the mussel..$^{7-9}$

The histology is necessary for the better investigation in development of gametes, and the quantitative estimations are important because they eliminate the subjectivity and the problems associated to the description. The study of the condition index is one of the methods retained to evaluate the potentialities of weight growth bound to the reproductive cycle. The reproductive tissue of sexually matured M. Galloprovincialis accounts for more than 59\% of the weight of the soft tissue. ${ }^{10}$ or more than $95 \%$ of the mantle. Reserve cells in the mantle, the ADG cells, has been observed in histological specimen, and the seasonal variation of number of ADG cells has been investigated.$^{4,11}$ The stored nutrients are released during gametogenesis; this mobilization of reserves is followed by a phase of active reserve during the period of sexual rest. The process is also able to be observed through histological analyses. Unfortunately, investigation in the mussels with histological analyses is limited in Moroccan water excepting in Mediterranean Sea population of $M$. galloprovincialis ${ }^{4}$ No work has been done in the Atlantic region in Morroccan water. This study investigates the annual successive cycles of the reproductive activity of gametes in the Atlantic coast of Morocco. The status of gonad development and the reserves cells at the peak of spawning were histologically analyzed.

\section{Material and methods}

\section{Study area and sampling site}

The coastal shelf of Cap Beddouza ( $32^{\circ} 32^{\prime} 24^{\prime \prime} \mathrm{N}$; 9 $9^{\circ} 16^{\prime} 48^{\prime \prime} \mathrm{W}$ ), also called Cape Cantin, was our study area. This cape is isolated from major human activities and away from any industrial or agricultural activities because of the landscape. The coast line is steep, surrounded by high cliffs reaching $60 \mathrm{~m}$. The area is the part of the Middle Atlas mountainous area, extended into the Atlantic Ocean. Despite of the steep coastline, sea bed slope are from 0.3 to $0.7 \%$. The costal shelf broadly extends to $30 \mathrm{~km}$ of the coastline, and $100-\mathrm{m}$ isobath is located at $20 \mathrm{~km}$ of the coast. The major current comes from the northwest. The semi diurnal tide has a maximum level $(3.60 \mathrm{~m})$ in spring tide and $0.7 \mathrm{~m}$ in neap tide. The prevailing winds are generally from the north and moderate. In winter, wind direction changes to South-West wind, and the most intensive wind prevail from the southwest. 
Samples were collected made every month along the coast of Cap Beddouza from March 2009 to March 2011 (Figure 1). Every sampled set at individual survey contained thirty adult individuals of $M$. galloprovincialis. The sampling was made in low tide, and samples were transported in the laboratory for measurement, dissecting and histological analysis. During sampling, temperature was recorded at each survey at $30 \mathrm{~cm}$ of depth of the sampling site. It was measure during conductometer (WTW LF197).

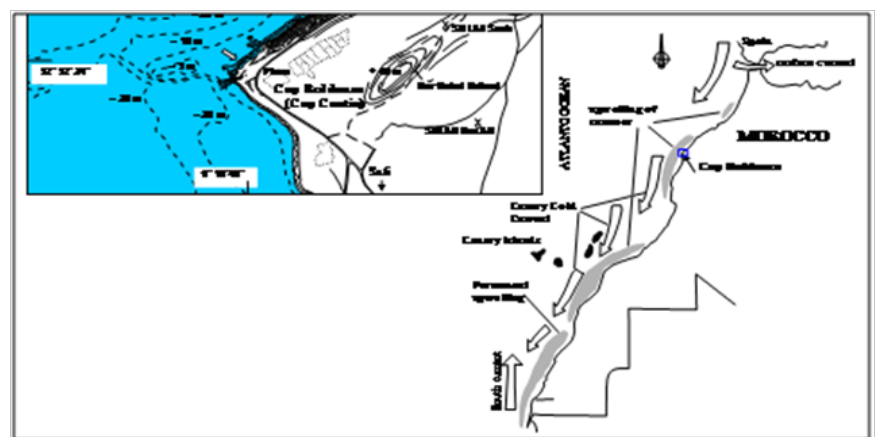

Figure I Situation plan of the sampling place Cap Beddouza; the steep coast lined with big cliffs of $60 \mathrm{~m}$.

In laboratory, the weight was measured before the opening of the shell. After opening mussel, the adductor muscle was removed from shell $(\mathrm{Wc}, \mathrm{g})$ to weigh fresh flesh (Wf, g) and shell (Wt, g) separately. We applied condition index to quantify the development of gonasomatic tissue relative to the content within the individual $M$. galloprovincialis :

The individual $M$. galloprovincialis was microscopically examined for gonadal development. The gonadal tissue for every $M$. galloprovincialis was fixed Davidson's solution during 24 hours. After dehydration in a graded ethanol series before embedded in paraffin, the tissues were sliced in $2 \mu \mathrm{m}$ thick and then stained by using hematoxylin andeosin. The sex of the specimen was determined during the histological processing. To determine the reproductive states of M. galloprovincialis, gonad development stage was classified into seven stages using the method defined by. ${ }^{11}$ and applied in Ojea et al. ${ }^{12}$ Benomar et al. ${ }^{13}$ and Bhaby et al. ${ }^{4}$ Gonadic index (GI, Seed, 1975) was applied to each stage of maturity: Index 1 (stage 0 and stage IIID); Index 2 (stages I, II, IIIB and stage IIIC), Index 3 (stage IIIA).GI were calculated as the following formula of Seed (1975):

$$
G I=\frac{\sum n i \cdot S i}{N}
$$

Where ni: Number of individuals at each stage of reproductive cycle, Si: score of the stage and $\mathrm{N}$ : total number of individuals. Monthly mean of the GI were calculated, and the time series of GI was analyzed through the seasons. Gametogenic development was indicated by increases of the monthly GI while decline in the time series indicates that occurrence of spawning. To quantify adipose-granular ADG state of $M$. galloprovincialis, we used the method suggested by Bignell et al. ${ }^{14}$ Four levels of ADG states were determined: Index 4 (ADG abundant cells constitute the major part of the connective tissue) index 3 (ADG common cells) index 2 (ADG cells spread over the mantle) index 1 (ADG trace cells) index 0 (ADG imperceptible cells).

In all statistical analyses, R version 2.15.2 (R. Core Team) was applied. After exploratory analyses and normality test with adequate transformations, seasonal variability of the condition index, were tested by one-way ANOVA. The Kruskal-Wallis test was applied to examine seasonal differences in gonadic and ADG indices with consideration in the normality of the data. The Chi-square test was used to compare the observed variation of the sex ratio to the proportion 1:1. All hypotheses were tested at the level of $\alpha=0.05$.

\section{Results}

\section{Temperature}

The water temperature changed between $15^{\circ} \mathrm{C}$ and $21^{\circ} \mathrm{C}$ from March 2009 to February 2011 (Figure 2). The temperature was lower than $17^{\circ} \mathrm{C}$ in winter and spring and higher than $17^{\circ} \mathrm{C}$ in summer and autumn. The maximum was in September $2009\left(21^{\circ} \mathrm{C}\right)$. On the other hand, the minimum temperature was recorded in March 2009. There was a distinct difference in the spring to summer temperature change between 2009 and 2010; the temperature from May to August was highly variable between $17^{\circ} \mathrm{C}$ and $19^{\circ} \mathrm{C}$ in 2009 though it raised as the change of the season in 2010 .

\section{Sex ratio}

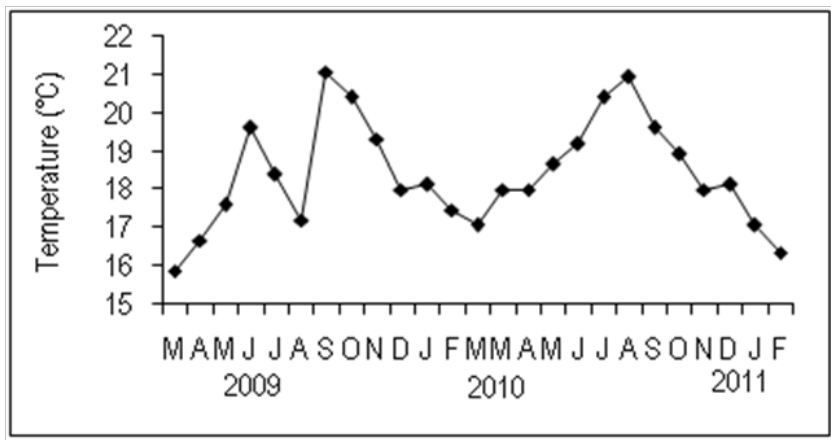

Figure 2 Variation of the temperature of the surface sea water in Cap Beddouza between March 2009 and March 2011.

In 750 specimens observed by microscope, 345 females, 400 males and 2 hermaphrodites were observed with three unidentified individuals. The hermaphrodites are recorded as females. The sex ratio was not significantly different from the theoretical sex ratio, 1/1 (Table 1).

Table I Chi-square test on the sex ratio of sampling mussels in the study site Cap Beddouza

\begin{tabular}{lllllll}
\hline Independent Variable Sex & Observed Staff & Theoretical Number ddl & X2 & P-Value \\
\hline \multirow{2}{*}{ Cap Beddouza } & Female & 347 & 373.5 & I & \multirow{2}{*}{0.052} & 1.88
\end{tabular}

\section{Reproductive cycle}

We observed all gametogenic stages in the specimen.

1. Stage 0: phase of sexual rest (no genital products) during which the mussels from this population were infected by an important intensity of a trematode.
2. Stage I: genital activity and multiplication of oogonies were started in the mantle. This last accumulated adipogranulate reserves cells.

3. Stage II: It was the beginning of the maturation of sex cells and decrease of reserves cells. 
4. Stage III: Stage of the sexual maturity and the emission of gametes. Inside this stage, we distinguished four phases:

5. Stage IIIA: for the males, sperm cells appeared at the level of the opening of follicles. The spermatozoids were arranged in small strips. About females: the oocytes presented a shape polygonale due to the pressure exercised because of their strong density in the follicle.

6. Stage IIIB: it was total or partial spawning of the male and female gametes.

7. Stage IIIC: Restoration activated of the gonad leading to a new phase of repletion of gonads. This phase was persisted until the reserves of ADG cells become insufficient.

8. Stage IIID: following the last draining of gonadic tubules, the reserves it metabolites began to appear and follicles collapsed and degenerated.

The gonadic activity shows the effective presence of all stages but with a very marked difference in times (Figure 3 ). The stage IIID and stage 0 , post-spawning stages were observed from spring to summer. These post-spawning stages were most frequently observed in early summer, from May to July. The stages I and II were highly observed in last summer and in autumn. In last autumn and in early winter, November December and January, stage IIIA took place up to a maximum. The spawning (stage IIIB) was continued with the starting up of the gametogenesis (stage IIIC) at the beginning of the winter throughout of the spring. The highest proportion of mussels sampled in stage IIIB or stage IIIC was respectively observed in February, March and April.

\section{Gonadic index}

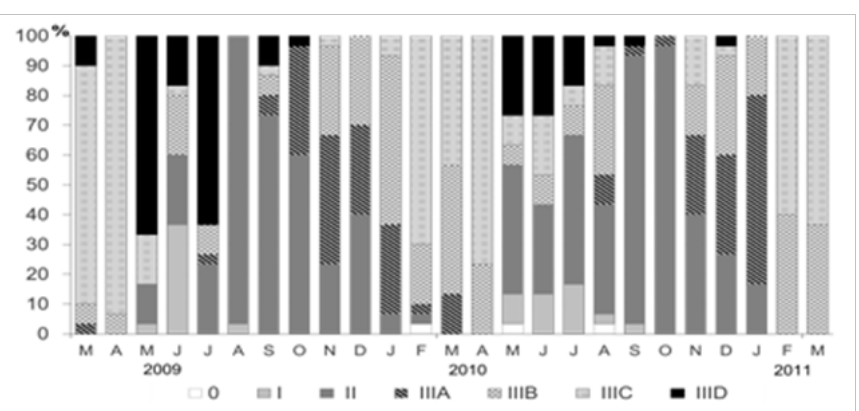

Figure 3 Monthly distribution of proportion of Mytilusgalloprovincialis between March 2009 and March $201 \mathrm{I}$.

The gonad index illustrated in the Figure 4, was showed high value (2.6) in winter which the histology indicated an advanced level of maturity (stage IIIA). The lowest value (1.3) of gonadic index was recorded in summer, which revealed the period of post-spawning (Figure 5). The Kruskal-Wallis test indicated that there were, in relation to the seasons, there was a significant contrast of gonad activity ( $p$-value $<0.05$ ). This result was also well illustrated by the box plots (medians particularly differentiated).

\section{Adipogranular index (ADG)}

The Adipogranular cells (Figure 4) were imperceptible in spring from February to April. They began to manifest so scattered (index 2) in last spring in May, and in November and January. Their presence becomes dominant (index 3 and 4) from June to October (years 2009 and 2010) (Figure 5), the peak being reached in August and September, which was the consequence of the invasion of cells reserves in the mantles. The proliferation of those cells was indicated the end of a cycle and announced at the same time a start of new cycle. However, to perform a seasonal approach, we have been prepared the corresponding box plots; which they showed a marked asymmetry in the distribution of the ADG index. The Kruskal-Wallis test was validated the observed seasonal box plots differences ( $p$-value $<0.05$ ).

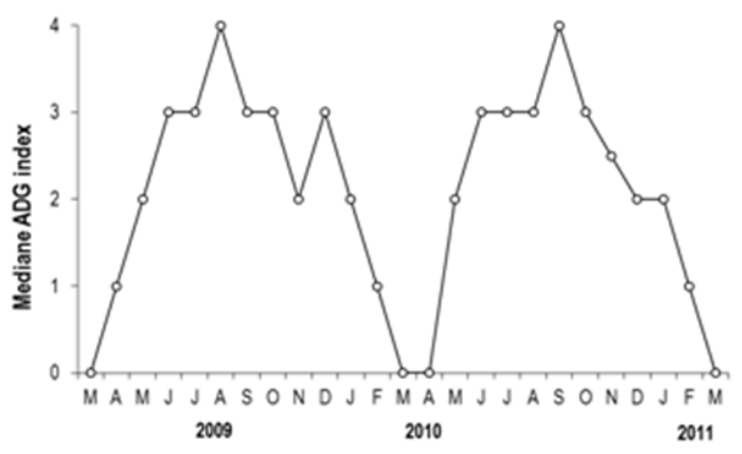

Figure 4 Monthly evolution of the ADG index of Mytilusgalloprovincialis between March 2009 and March 2011 in Cap Beddouza.

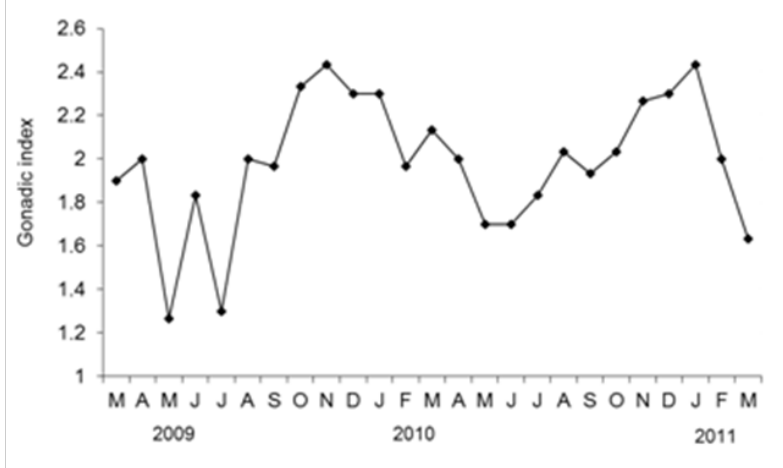

Figure 5 Monthly gonadic index of Mytilusgalloprovincialis in Cap Beddouza between April 2009 and March 201 I.

\section{Condition index}

The condition index (Figure 6) oscillated regularly and gradually around the average of $44 \%$. The maximum value was recorded in winter and in autumn, it was produced in January 2010, where are corresponded to the gonadal maturity in almost all individuals. The accumulation of reserve cells which was observed in September 2010 was also demonstrated by a maximum value of condition index. In the spring, the condition index measured was lower. This last period corresponded to the phase of massive spawning. It was recorded in April and May. Condition index showed significant responses to the season which was perfectly illustrated by the box plots (ANOVA, p-value $<0.05$ ) (Figure 7).

\section{Discussion}

Cap Beddouza divided up in a characteristic environment of the Moroccan Atlantic center coast, where characterized by upwelling in summer. This work is the first studies have been carried out the biology of Mytilusgalloprovincialis and especially its reproductive cycle in this area. To know all details of the reproductive cycle is important to make a success of the breeding. It can be used to master effective techniques for the conditioning; induction of spawning and embryonic development. We analyzed the gametogenesis processing of mussels in relation to their reserve accumulation and weight 
differences. Seasonal variability of these analyses was also evaluated. This work showed that in the center of Morocco (Cap Beddouza), the mussels were characterized by a synchronous gametogenesis broadly overlapping reproductive cycle, with gametogenesis taking place over the entire year. The found synchrony was unique in the populations other waters in Moroccan coast, where gonad development cycle was individually different., ${ }^{45}$

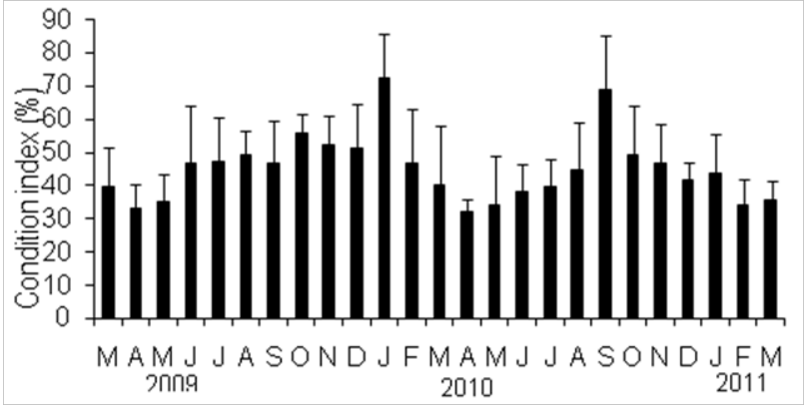

Figure 6 Evolution of the average condition index of the population Mytilusgalloprovincialis in Cap Beddouza.
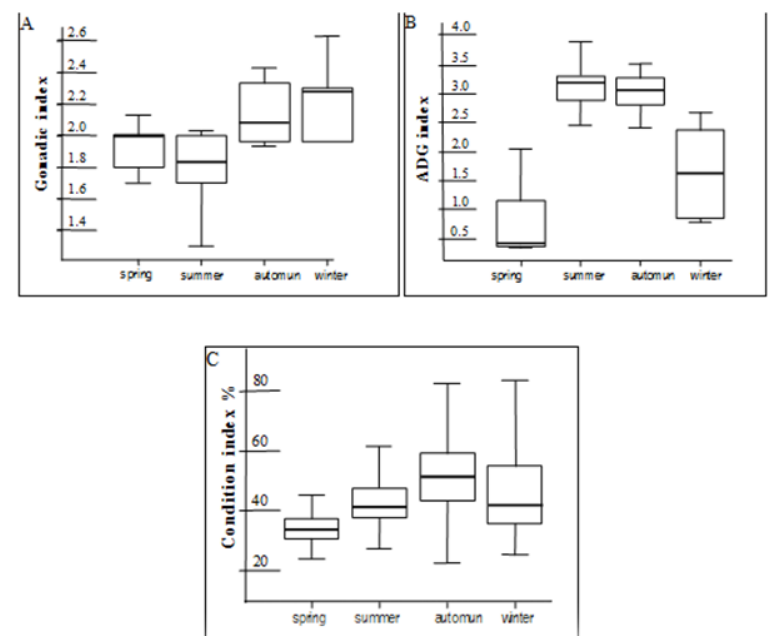

Figure 7 Box plots comparative indices, highlighting the seasonal differences of the studied biological parameters. (A) Gonadic index: sensitive dispersal. (B) Simultaneity variations of the ADG cells reserves. (C) Condition index: amplitude, displayed seasonal gaps.

To determine the status of gonad development, we used three biological indecies parameters: the gonadic index, the condition index and the ADG index. On the basis of results, we can say that the reproductive cycle of the natural population $M$. galloprovincialis in this area is particularly sensitive to the event of the seasons. The gametogenesis begins in summer, continues until the end of autumn. This event is coincided with the higher presence of ADG cells and the beginning of the increase of condition index. The mussels Mytilus galloprovincialis contained ripe gonads at the beginning of the winter until spring when the peak of spawning was observed. In fact, the spawning start in winter and remains till the end of the spring. This report is in accordance, in a similar result, with the observations of Villalba A. ${ }^{6}$ Seed R. ${ }^{16}$ Shafee MS ${ }^{17,18}$ In particular, the fold of the ADG cells and it's collapse of the condition index coincide with mass spawning period; this correlation was already identified by Bignell et al. ${ }^{14}$ in their work from English coast and Bhaby et al. ${ }^{4}$ in south of Morocco. The massive spawning is translated by a notable hollow of the condition index. Besides, from May to July, the gametogenesis is enlivened and shaken: all stages are present and there is ascendancy, from the final phase to the phase of initiation. We can reasonably connect this continuity with the oceanographic regime which reigns in this region, seen that the temperature undergoes sensitive variations during this period. It joins the conclusions of the following authors: Lemaire et al. ${ }^{9}$

\section{Acknowledgements}

The outcome of this work owes to the entire staff of the l'Institut national de la Recherche Halieutique Morocco. That each finds here the expression of our profound gratitude.

\section{References}

1. Comesana AS, posada DA, Sanjuan Mytilusgalloprovincialis in Northern Africa. Journal of experimental marine biology and ecology. 1998;223:271-283.

2. Federation des industries de transformation et de valorisation des produits de la peche (FENIP). Étude de l'état des lieux de l'aquaculture au maroc, p. 2010;7-14.

3. Halla M, Bouhaimi A, Zekhnini A, et al. Etude du cycle de reproduction de deuxmoules Perna perna (linné 1785) et Mytilus galloprovincialis (lamark 1819) dans la baied'agadir (sud du maroc). Haliotis. 1997;26:51-62.

4. Bhaby S, Belhsen OM, Errhif A Mytilus galloprovincialis; Reproduction activity and mantle structure in a zone located in the northwest of the Atlantic Ocean (imessouane, morocco). J mar biol Oceanogr. 2014;3(1).

5. Bhaby S, Belhsen OM, Errhif A Mytilus galloprovincialis: reproductive cycle of fields mussels close to a lagoon (North Atlantic, moulay bousselham, morocco). J mar Biol Oceanogr. 2015;4(1).

6. Villalba A Gametogenic cycle of cultured mussel, Mytilus galloprovincialis, in the bays of Galicia (N. W. Spain). Aquaculture. 1995;130(2-3):269-277.

7. Morchid A La reproduction des moules Mytilus galloprovincialis lmk. En élevage dans le golfe de fos, aspects biologiques, biochimiques et bioénergétiques. These univ, Marseille, pp. 1987;116.

8. Gray AP, Seed R, Richardson CA Reproduction and growth of Mytilus edulis chilensis from the Falkland Islands. Scientia marina, 61(Supl 2): 1997;39-48.

9. Nahrgang J, Brooks SJ, Evenset A, et al. Seasonal variation in biomarkers in blue mussel (Mytilus edulis), Icelandic scallop (Chlamys islandica) and Atlantic cod (Gadus morhua): implications for environmental monitoring in the Barents Sea. Aquat Toxicol. 2006;127:21-35.

10. Thompson RJ. Fecundity and reproductive effort in the blue mussel (Mytilus edulis), the sea Urchin (Strongylocentrotus droebachiensis) and snow crab (Chionoecotes opilio) from populations in Nova Scotia and Newfoundland. J Fish Res Board can. 1979;36(8):955-964.

11. Lubet P. Recherchessur le cycle sexueletl' émission des gamètes chez les mytilidés et les pectinidés. Revue des travaux de l'institut des pêchesmaritimes. 1959;23(4):395-548.

12. Ojea J, Pazosb AJ, Martinez D, et al. Seasonal variation in weight and biochemical composition of the tissues of Ruditapes decussates in relation to the gametogenic cycle. Aquaculture. 2004;238(1-4):451468.

13. Benomar S, Bouhaimi A, EL Hamidi F, et al. Cycle de reproduction de la moule africaine Perna perna (Mollusca, Bivalvia) dans la baie d'Agadir: Impact des rejets d'eaux usees domestiques et industrielles. Biologie \& sante. 2006;6(1).

14. Bignell JP, Dodge MJ, Feist SW, et al. Mussel histopathology: effects of season, disease and species. Aquatic biology. 2008;2:1-15. 
15. Bhaby S, Belhsen OK, ErrhifA. Mytilusgalloprovincialis; gametogenesis of a colony of mussels in a fish breeding environ ment (Alboransea, M'diq, Morocco). J Fisheries and Aquaculture. 2013;4(2):110-114.

16. Seed R. Reproduction in Mytilusedulis linnaeus in European waters. Pubblicazioni della stazione zoologica di Napoli. 1975;39:317-334.
17. Shafee MS. Reproduction of Perna picta (Mollusca: Bivalvia) from the Atlantic coast of Morocco. Marine ecology progress series. 1989;53:235-245.

18. Mathieu M, Lubet P. Storage tissue metabolism and reproduction in marine bivalves - a brief review. Invertebrate reproduction and development. 1993;23(2-3):123-129. 